\title{
The socio-economic variables, parental involvement and academic performance of pupils
}

\author{
Opeyemi Olumayowa Shoaga ${ }^{1}$,Simidele Rasheed $^{1}$ \\ 1-Department of Educational Foundations and Counselling, Olabisi Onabanjo University, Nigeria \\ Corresponding author contact: shoaga.opeyemi@oouagoiwoye.edu.ng
}

\begin{abstract}
The study examined the influence of socio-economic variables (parents' income and parents' educational background) and parental involvement on academic performance of pupils. The survey research design was adopted for the purpose of this study. A sample of 200 pupils in primary four was randomly selected from 10 basic schools for the study. Three research questions were raised and tested for the study. Data were collected using Questionnaire. Data were analysed using Analysis of Variance and Pearson Product Moment Correlation statistics. Significant difference existed in the academic performance of pupils based on their parents' income while no significant difference existed in the academic performance of pupils based on their parents' educational background. Furthermore, significant positive relationship was observed between parental involvement and academic performance of pupils. Findings of this study recommends among others that schools managers should develop intervention programmes aimed at addressing the strategies that will help the improvement of the quality and consistency of parental involvement in their children's education activities if they anticipate better academic performance.
\end{abstract}

Keywords: Academic Performance, Parents' educational background, Parents' income, Parents' involvement, Socio-economic

\section{Introduction}

\subsection{Background to the Study}

Parents, teachers and other stakeholders are concerned about the academic outcome of the children in their care because this will determine the academic achievement of the children in the long run. Academic outcome represents the cognitive, affective and psycho-motor domains that pupils develop through their course of work and other educational experiences at school. Academic outcome of a pupil can also be identified as the measurable and observable behavior of a pupil in a specific situation.

Improving pupils' academic performance has been one of the utmost of the government, educators and researchers in Nigeria because of the persistent poor academic performance of learners generally. There are a lot of challenges with the system in view of the poor performance recorded by students in public examinations in the recent years (Adepoju, 2002; Adepoju \& Oluchukwu, 2011; Ajayi, 1998; Owoeye, 2000). As a result of this, factors that positively or negatively impact on learners' academic performance attracted huge research interests in the recent past. Most of these studies focused on school characteristics, teacher behavior, students' home background, family structure, student characteristics and study habits (Ayodele \& Adebiyi, 2013).

Meanwhile, the dynamic of other variables that can influence academic performance of learners such as the socio-economic variables and parental involvement have received little research attention in Nigeria especially studies pertaining to pupils of primary school because most the studies conducted 
are concerned mainly with secondary school or higher institutions students, and since the primary education is the foundation of all other learning, there is therefore need to investigate how these variables could influence the academic performance of pupils.

The socio-economic variables are those factors that are attached to one's life which can affect an individual in one way or the other. Socio-economic variables affect man in all ways like academically, physically, emotionally, morally, socially, etc. But this study is concerned with the academic aspect and how it affects the academic performance of pupils. The socio-economic variables are parental income, investigating how parental income and parents academic background, ethnicity, gender etc. However, this study is interested in investigating how parental income and parents academic background influences academic-performance of pupils.

Parents' income is the wages or salaries that are earned by parents. It is the payment given one's father or mother after work or income generated through personal merchandise. The parent's income, either high or low have been said to have impact on students' academic performance. This assertion has generated a lot debate because some studies conducted found that parents that have high income tend to enroll their children in standard schools with instructional resources and facilities that will aid their children's leaning and these gives them an edge above children from low family income. Significant relationship existed between parent socio-economic status, parents' level of income, family size, parents' educational status, and students' academic achievement (Ogbugo-Ololube, 2016). On the other hand, students who mostly come from disadvantaged socio-economic background have been identified to perform relatively better than those from higher socio-economic background (Pedrosa et al., 2006 cited in Ali, Haider, Munir, Khan, \& Ahmed 2013). From the foregoing there is need to ascertain if the parents' income influences academic performance of their children.

Parent's educational background is another variable under socio-economic variables that could affect pupils' academic performance. The relationship that existed between parents' academic background and that of their children may be because of some unobserved biological qualities rather than an informal effect of parental education (Ogbugo-Ololube, 2016). Parental education may also contribute to the production function that generates a higher quantity of other inputs through the effect of educational levels of household income (Ogbugo-Ololube, 2016). Parents or guardians have educational, economic and social advantages which strengthen high level of success in children or wards future academic endeavor (Ali, Haider, Munir, Khan, \& Ahmed, 2013; Considine \& Zappala, 2002). However, parents provide adequate emotional and psychological support for their children by making provision for good learning and educational environment that instill confidence and the required skills needed to succeed (Ali, R., Haider, Munir, Khan, \& Ahmed, 2013; Considine \& Zappala, 2002). Despite all these assertions there is still need to ascertain these because the studies were conducted in other cultures and countries and mostly on secondary or higher institutions students not on primary schools pupils.

Besides socio-economic variables another factor that could possibly influence academic performance of pupils is parental involvement. Parental involvement refers to parents' encouragement and interest in their children's education and their attitude towards school and classroom conduct, absenteeism, self-esteem and motivation (Baranek, 1996; Ogunjinmi, Salami, \& Oyedare, 2015; Topor, Keane, Shelton, \& Calkins, 2010). Parental involvement has to do with shared responsibility between the home and school in enhancing students' academic achievement (Bailey, 2017). Also, parental involvement is regarded as an all en-compassing term which includes responding to school obligations, attending to the child's school functions, supporting children to do their work, by encouraging them and helping them to arrange for appropriate time of study and space, modeling acceptable behavior, monitoring homework and keenly involved in teaching children at home (Cotton \& Wilkelund, 2001; cited in Zoppi, 2006).

Research findings revealed that parents' involvement in their child's education enhances their academic success (Gicobi, 2017; Ogbugo-Ololube, 2016; Thornton, 2015). Chen (2008) is of the opinion that involvement of parents improves academic performance. He emphasised that academic performance is improved upon when parents are committed to the education of their children and he also posited that the more involved parents are, the better the chances for improved impact on academic success. The involvement of parents in their children's education is believed to be one of the most 
significant aspects of academic achievement and it is believed to promote the relationship between home and school (Thornton, 2015). This also corroborated the findings of Mwirichia (2013) which showed that various forms of parents' participation in educational activities at school; education activities at home, parent-school communication and home environment had an influence on the academic performance of preschool learners.

However, some other studies outside Nigeria have proved otherwise, for instance, a study of Steinberg et al. (1994) which conducted among African Americans shows that neither the parental involvement nor encouragement was having any significant predictive value on the adolescent students' academic performance. Significant difference subsists between the academic performance of underperforming students from low socio-economic background and those from high socio-economic background in Oyo State, Nigeria (Adelodun, 2013).

Thus, there is inconsistency, on the predictive role of parental involvement on academic performance of students and besides little works as been done as at how it relates with children of younger age. It is against this backdrop that this study wants to investigate how socio-economic variables and parental involvement affects the academic performance of pupils in Ogun State, Nigeria.

\subsection{Statement of the Problem}

Pupils home has been examined in many international studies as strong predictor of their academic performance. Some researchers found that the high socio-economic status is associated with achievement. However, reports across different findings have been inconsistent across cultures, suggesting a possible cultural difference. Also, there is controversy on the predictive role of parental involvement on the academic performance of learners. It is against this backdrop that this study seeks to examine socio-economic variable, parental involvement and academic performance of pupils in Ogun State.

\subsection{Research Questions}

The following questions were raised for this study:

1. Is there any significant difference inthe academic performance of pupils based on their parents' income?

2. Is there any significant difference inthe academic performance of pupils based on their parent educational background?

3. What is the relationship between parental involvement and academic performance of pupils?

\section{Methodology}

\subsection{Research Design}

Cross Sectional Survey research design was adopted for the study.

\subsection{Participants}

The target population was all the primary four pupils as well as their parents in Ijebu north Local Government Area of Ogun State. The sample consisted of 200 pupils and their parents. A simple random sampling technique was used to select 20 pupils from 10 basic schools. In schools with more than one arm, one arm was selected through random sampling and subsequently 20 pupils were randomly selected from the intact class. 


\subsection{Instrument}

Two instruments were used to elicit responses from the respondents. Demographic data inventory and parental involvement scale were used for collecting responses on socio-demographics and parental involvement while achievement tests from unified examination in public primary schools were used for data collection on academic achievement. Parental Involvement scale was developed by Voydanoff and Donnelly, 1999 to measure how involved a parent or parents are in lives of their children. The scale has nine items and the reliability coefficient was found to be 0.71 . The scale has been used by other researchers in Nigeria and was found to be cultural bias free.

\subsection{Procedure}

The researchers went to ten schools and twenty primary four pupils were randomly selected in each school sampled and they were given questionnaires to fill; these pupils were also given questionnaires home to give to their parents, that is, the questionnaires meant for parents. The researchers went back to collect the questionnaire from the pupils. Person Product Moment Correlation and Analysis of Variance (ANOVA) were used to analyze the data collected.

\section{$3 \quad$ Results}

Research question 1: Is there any significant difference inthe academic performance of pupils based on their parents' income?

Table 1: Comparison of pupils' academic performance

\begin{tabular}{|l|l|l|l|l|l|}
\multicolumn{7}{|c|}{ based on parents'income } \\
\hline Between groups & Sum of squares & df & Mean Square & F & Sig. \\
Within groups & 1566.943 & 2 & 273.471 & 3.432 & 0.034 \\
Total & 16243.577 & 197 & 79.678 & & \\
\hline \multicolumn{7}{|c|}{$p<.05$} & & \\
\hline
\end{tabular}

The result in Table 1 revealed a significant difference $(\mathrm{F}=3.432, \mathrm{p}<0.05)$. This implied that there is a significant difference inthe academic performance of pupils based on their parents' income.

Research question 2: Is there any significant difference inthe academic performance of pupils based on their parents' educational background?

Table 2: Comparison of pupils' academic performance based on parents' educational background

\begin{tabular}{|l|l|l|l|l|l|}
\hline & Sum of squares & df & Mean Square & F & Sig. \\
\hline Between groups & 208.843 & 2 & 104.421 & 1.283 & 0.280 \\
Within groups & 16034.677 & 197 & 81.394 & & \\
Total & 16243.520 & 199 & & & \\
\hline
\end{tabular}

The result in Table 2 revealed a non-significant difference $(\mathrm{F}=1.283, \mathrm{P}>0.05)$. This implied that there is no significant difference inthe academic performance of pupils based on their parents' educational background.

Research question 3: What is the relationship between parental involvement and academic performance of primary four pupils? 
Table 3: Relationship between the independent and dependent variables

\begin{tabular}{|l|l|r|r|}
\hline & & Academic performance & Parental involvement \\
\hline Academic performance & Pearson correlation & 1 & $-142^{*}$ \\
& sig. (2-tailed) & & 0.044 \\
& $\mathrm{~N}$ & & 200 \\
\hline Parental involvement & Pearson correlation & $-0.142^{*}$ & 1 \\
& sig.(2-tailed) & 0.044 & 200 \\
& $\mathrm{~N}$ & 200 & \\
&
\end{tabular}

Table 3 above revealed that there is a relationship between parental involvement and academic performance of primary four pupils $\left(\mathrm{r}_{(200)}=-0.142^{*} ; \mathrm{P}<0.05\right)$; by implication, there exists a negative relationship between parental involvement and the criterion of primary four pupils.

\section{Discussion}

The first finding in this study showed that there was a significant different in the academic performance of primary four Pupils based on their parents' income. It has also been discovered that children from low income families are pre-disposed to high risk of underachievement, educationally. (Arias \& De vos, 1996). Also, pupils with low income background are more disadvantaged in many areas such as deleterious placements during school hours, poor grade retention, and inability to complete their primary school level of education. Educational facilities in poverty ridden areas are pre-disposed to situations that undermine pupils from learning in a safe environment. (Arias \& De vos, 1996). In the same vein, children from poor homes are more likely to suffer fatigue, flu and cold, headaches, irritability, hunger, ear infections and so on. These illnesses could limit a child's ability to focus and concentrate. However, pupils from high income background have favorable environment and are exposed to a variety of educational materials (Wood, 2002).

Pupils from high income background have ample time to stay back at school as their parents are able to fund their education and other contributions expected of them (Best \& Khan, 2006). This therefore suggests that pupils who come from low income families may be less successful in terms of education than pupils who live in families with high income background. A positive correlation exist among family income and the academic achievement of the students under study have also been reported (Amazu \& Okoro, 2015). The result of this study showed that the revenue generated by the family significantly determines the educational outcomes of their children.

The second finding in this study discovered that there was no major difference in the academic performance of primary four Pupils based on their parents' educational background. This result is contrary to that which found a correlation between parents' educational status, socio-economic status, family size, parents' level of income, and students' academic achievement (Ogbugo-Ololube, 2016). The findings of Amazu and Okoro (2015) also showed that children whose parents had more formal education tended to achieve more than their peers whose parents had comparatively lower education.

The third finding in this study revealed that there is an affiliation between parental involvement and the academic performance of primary four pupils. This result corroborated the findings of Ibaara and Ndirangu (2014) that discovered that Parents' involvement is beneficial to their children's education progress while it contradicted the findings of Adelodun (2013) that showed that there was no significant difference among the academic performance of underperforming students whose parents are of low income background and those whose parents are of high income background in Oyo State, Nigeria.

\section{Conclusion and Recommendations}

This study had shown that parents income and involvement had great influence on the academic performance of pupils in primary schools. Based on these findings it was recommended that schools managers should develop intervention programmes aimed at addressing the strategies that will help the improvement of the quality and consistency of parental involvement in their children's education 
activities if they anticipate better academic performance. Parents should learn to create time for their children's academic work. Most especially, the fathers or single parent should be sensitize on the vital position their involvement would create in their children's education.

\section{References}

Adelodun, G.A. (2013). Parental Involvement as a determinant of academic performance of gifted underachieving students in Akinyele Local Government Area of Oyo State. Journal of Education and Practice. 4(17), 144- 148

Adepoju, T. L. \&Oluchukwu, E. E.(2011). A study of secondary school students' academic performance at the senior school certificate examinations and implications for educational planning and policy in Nigeria. An International Multidisciplinary Journal, Ethiopia, 5 (6), 314-333.

Ajayi,I.A. (1998). Unit cost of Secondary education and students' academic achievement in Ondo State, Nigeria (1991-1995). An Unpublished Ph.D thesis University of Ibadan, Nigeria.

Ali, R., Haider, Z., Munir, F., Khan, H., \& Ahmed, A. (2013). Factors contributing to the students' academic performance: A case study of Islamia University Sub-Campus. American Journal of Educational Research, 1(8), 283-289. doi: 10.12691/education-1-8-3

Amazu, N. A. \& Okoro, C. C. (2015). Social status of parents and students' academic performance in Aba Educational Zone, Abia State. Advances in Research, 3(2), 189-197.

Arias,E., \& De Vos, S. (1996). Using Housing Items to indicate Socioeconomic Status: Latin America. Journal of Social Indicators research, 38, 53-60. http://dx.doi.org/10.1007/BF00293786.

Ayodele, C. S., \& Adebiyi, D. R. (2013). Study habits as influence of academic performance of students' nurses of Banquet State University. International Journal of Nursing Science, 5(2), 60-65.

Bailey, T. (2017). The impact of parental involvement on student success: school and family partnership from the perspective of students. Doctor of Education in Teacher Leadership Dissertations. 22. http://digitalcommons.kennesaw.edu/teachleaddoc_etd/22

Baranek, L. K. (1996). The Effect of Rewards and Motivation on Student Achievement. Masters Theses. 285. http://scholarworks.gvsu.edu/theses/285

Best, J.W. \& Kahn, J.V. (2006). Research in Education. 10 ${ }^{\text {th }}$ Edition, Pearson Education Inc., Cape Town.

Chen, H.F. (2008). The longitudinal factor structure of parent involvement and its impact on academic achievement: findings from the ECLS - K data set. Pro Quest Dissertations, University of Denver, Denver, Colo, USA.

Considine \& Zappala. (2002). The influence of social and economic disadvantage in the academic performance of students in Australia. Journal of Sociology 38(2), 129-148.

Gicobi, M. F. (2015). Parental Involvement in Pre-Primary Children's Education: An Implication on their Performance in Kabare Education Zone, Kirinyaga County, Kenya. An Unpublished Master of Education Thesis, Kenyatta University, Kenya.

Kibaara, T. M. \&Ndirangu, L. M. (2014). Parental involvement in their children's academic achievement in public secondary schools: A case of Kieni-West Sub-County, Nyeri CountyKenya. International Journal of Education and Research, 2(11), 411-424.

Mwirichia, V. M. (2013). Influence of Parental Involvement on Academic Performance of Preschool Children in Kangeta Division, Meru County, Kenya. A Masters of Education thesis, University of Nairobi.

Ogbugo-Ololube, R. (2016). Impact of Students' Parental Background on Academic Achievement in Secondary Schools in Obio/Akpor LGA, Rivers State, Nigeria. International Journal of Scientific Research in Education, 9(2), 115-126.

Ogunjinmi, O., Salami T., \& Oyedare, O. (2015). Parents and Students Interest as Determinants of Students' Academic Performance in Agricultural Science in selected Secondary Schools in Oyo 
Metropolis, Oyo State. International Journal of Academic Research in Progressive Education and Development 4(4), 14-19. doi: 10.6007/IJARPED/v4-i4/1864

Owoeye, J.S. (2000). The effect of interaction of location, facilities and class size on academic achievement of Secondary School Students in Ekiti State, Nigeria. An Unpublished Ph.D thesis University of Ibadan, Nigeria.

Pedrosa, et al. (2006). Educational and Social economic background of graduates and academic performance: Consequences for affirmative action programs at a Brazilian research University.

Steinberg.L., Lamborn. S., Darling N., Mounts. N., \& Dornbusch,S. (1994). Overtime changes in adjustment and competence among adolescents from authoritative, authoritarian, indulgent and neglectful families. Child Development. 65, 754-770

Thornton, R. (2015). Parental involvement and academic achievement. All Capstone Projects. 114. http://opus.govst.edu/capstones/114

Topor, D. R., Keane, S. P., Shelton, T. L., \& Calkins, S. D. (2010). Parent involvement and student academic performance: A multiple mediational analysis. J Prev Interv Community, 38(3), 183 197. doi: $10.1080 / 10852352.2010 .486297$

Wood, C. (2002). Parent-Child Pre-School Activities can affect the Development of literacy Skills. Journal of Research in Reading, 24, 248-265

Zoppi, I. M. (2006). Latino parental involvement in students' school attendance and achievement. University of Maryland. Retrieved from: http://www.education.umd.edu/mimaue/index.html 